\title{
QUANTIFYING ILLEGAL DEFORESTATION IN FRONT OF THE FOREST CODE: POTENTIALITY AND CHALLENGE
}

\author{
Rejane Ennes Cicerelli ${ }^{1 *}$, Aline Brignol Menke ${ }^{2}$, Tati Almeida ${ }^{1}$, Henrique Llacer Roig ${ }^{1}$, Mauro Oliveira Pires ${ }^{3}$, \\ Nazaré Soares ${ }^{4}$
}

1*Universidade de Brasília, Instituto de Geociências, Brasília, Distrito Federal, Brasil - rejaneig, tati_almeida, roig@unb.br ${ }^{2}$ Ministério do Meio Ambiente, Brasília, Distrito Federal, Brasil - aline.menke@mma.gov.br

${ }^{3}$ Instituto Chico Mendes de Conservação da Biodiversidade, Brasília, Distrito Federal, Brasil - mauro.pires@icmbio.gov.br

${ }^{4}$ Centro de Gestão e Planejamento Estratégico-CGEE, Brasília, Distrito Federal, Brasil - nazarels2013@ gmail.com

Received for publication: 26/09/2018 - Accepted for publication : 28/01/2021

\begin{abstract}
Resumo
Quantificação do desmatamento ilegal frente ao Código Florestal: potencialidade e desafio. O Brasil enfrenta um grande desafio para implementar o Código Florestal, agora denominada Lei de Proteção da Vegetação Nativa (LPVN), decretado e sancionado em 2012 sob o número 12.651. Essa lei introduziu novos mecanismos para quantificar áreas irregularmente desmatadas em Áreas de Preservação Permanente (APP), e Áreas de Reserva Legal (RL). Assim, esse estudo apresenta uma proposta metodológica de quantificação de desmatamento irregular em áreas de preservação permanente de hídrica e reserva legal, utilizando ferramentas de geoprocessamento em média escala, considerando uma visão municipal. Para isso, foi necessária uma análise complexa, baseada no tamanho das propriedades rurais privadas, no tipo de uso/cobertura da terra e no "corte temporal", para o qual não há metodologia definida. O "corte temporal" foi definido para conceder benefícios àqueles que praticaram o desmatamento ilegal antes de 22 de julho de 2008, criando assim a figura das "Áreas Produtivas Consolidadas". Esta metodologia foi testada e aplicada no município de São Félix do Xingu-PA e os resultados apontaram a necessidade de recuperar 178.835 hectares até 2010. De acordo com os requisitos estabelecidos no artigo 61-A, os assentamentos foram considerados propriedades rurais com áreas produtivas consolidadas e, portanto, beneficiadas por lei. Apesar disso, é importante melhorar as técnicas de educação ambiental e adequação ambiental dos assentamentos, principalmente para fins de produção sustentável.

Palavras-Chave: Áreas de Preservação Permanente, Reserva Legal, Geoprocessamento, Adequação Ambiental.
\end{abstract}

\begin{abstract}
Brazil confronts a challenge to implement the Forest Code, now called Native Vegetation Protection Law (LPVN), issued in 2012 under the number 12.651/12. The law introduced new mechanisms to quantified environmental liabilities in Permanent Protection Areas (APP) and Legal Reserve Areas (RL). Thus, this study presents a methodological proposal for calculation of environmental liabilities in areas of "water" permanent preservation and legal reserve using geoprocessing tools. This way, a complex analysis was required, based on the size of the private rural properties, the type of land use/cover, and "temporal cut", for which there is no methodology defined. The "temporal cut" was defined to fine cancel those who practiced illegal deforestation prior to 22 July 2008, thus creating the figure of the "Consolidated Productive Areas". This methodology was tested and applied in the municipality of São Félix do Xingu-PA and the results pointed to a total environmental liability of the municipality of 178,835 hectares by 2010 . According to requirements established in article 61 A, the settlements were considered rural properties with consolidated productive areas, and thus benefited by law. Despite this, it is important to improve environmental education techniques and the recovering of environmental liabilities of settlements, mainly for sustainable production purposes.

Keywords: Permanent Preservation Areas, Legal Reserve Areas, Geoprocessing, Brazilian Forest Code, Environmental Adequacy.
\end{abstract}

\section{INTRODUCTION}

The quality of life of the society relies significantly on the environmental services provided by nature (GUEDES; SEEHUSEN, 2011). The Amazon region has a particularly important role in the conservation of biodiversity and in the Brazilian economic and strategic scenario, consisting in a greater extension of continuous humid tropical forest within a nation, characterized by a remarkable richness of species and high levels of endemism (MCNEELY et al., 1994). However, in the mid-1970s, official policies and subsidies and private action promoted their occupation, symbolized in the construction of major axes of infrastructure (roads, hydroelectric power plants and transmission lines) and the development of settlement projects, attracting migratory flows, which caused significant changes in land use and occupation (BECKER, 2010; BARNI et al., 2012; COUTINHO, 2009; MARTINI et al., 2015). 
As a way of minimizing the unfavourable scenario for the maintenance of biodiversity and the Amazon ecosystems, Brazil has established legal measures to protect or regulate the use of land in the region. These measures include, among others, the creation of conservation units and the drafting of an environmental legislation with land use restrictions (MACEDO et al., 2012; BOUCHER et al., 2013; DALLA-NORA et al., 2014). This legistation, published in 2012 under the number 12,651/12 (BRASIL, 2012), established new rules on the protection of vegetation in Permanent Preservation Areas (APP - acronym in portuguese) and Legal Reserve Areas (RL - Acronym in portuguese). These rules involve the use of a sequence of procedures and data that are not widely disseminated in the literature in medium-scale projects that seek to understand the territory occupation process.

. Regarding these criteria, geotechnology can be seen as the main technique for the methodological development and for monitoring land changes and land protection in observation of the law, because they provide an integrated and synoptic view over landscapes, providing clear identification of legal non-compliance areas.. Thereby the aim of this work is quantifying, regarding the information available, the irregular deforested areas in APP around rivers and RL in the context of Amazon biome, under the legal directives, since one of the greatest concerns in society is what is the amount of illegal deforestation, in compliance with Law $n^{\circ} 12,651$. For that, the municipality of São Félix do Xingu was selected as a study area, specifically within rural properties and protected areas such as Indigenous Lands (TI - acronym in Portuguese) and Conservation Units (UC - acronym in portuguese). This work intended to guide municipal action to undertake efforts and public policies for environmental recovery.

\section{MATERIAL AND METHODS}

The study area, municipality of São Félix do Xingu (SFX), is located in the southeast of the State of Pará, and is the third-largest of the state and the sixth-largest in Brazil and its total area is $84,231 \mathrm{~km}^{2}$. According to the Demographic Census of 2010, has a population of 91,340 inhabitants, which gives it a population density of 1.1 in hab/ $\mathrm{km}^{2}$. Except for APA Triunfo do Xingu, that bears special occupation regime by private properties given by Decree $n^{\circ} .2 .612$ of 12/04/2006, the municipality has $60 \%$ of its territory comprised by UC and TI.

This municipality is characterized by the extensive farming with very low-productivity. Frequently, this activity is carried out to ensure land ownership without minimal conditions of environmental and social sustainability practices, disregarding the guarantee of quality of life for the human being. . In addition, mining and illegal logging give the outline of the economic reality that marks the municipality and directly impacts the situation of its forest remnants (MACEDO et al., 2013).

In the Amazon, the most noticeable face of the farming frontier advance over the forest is reflected in the deforestation rates, measured annually since 1988 by Instituto Nacional de Pesquisas Espaciais (INPE) (National Space Research Institute). According to the INPE, by 2017 approximately 18,440 $\mathrm{km}^{2}$ were deforested, nearly $22 \%$ of the territory of São Félix do Xingu. Considering just the private areas, approximately $60 \%$ of these suffered clear cutting, concentrating mostly in the central-north part of the municipality (Figure 1). Considering the data from Degrad (Mapping Forest Degradation in the Brazilian Amazon) until 2016, in the municipality of São Felix do Xingu about $291 \mathrm{~km}^{2}$ of native forest have already suffered some degree of degradation showing a trend towards increasing rates of deforestation. To facilitate the methodological understanding adopted in this article, the term illegal deforestation mentioned above has been replaced by "environmental liability". In addition, the term remaining native vegetation, which exceeds the areas of water APPs and RL will be called "environmental assets".

For the execution of the work, validated and adjusted inputs for the study area were used, namely: (i) Rapideye images 2011 and 2012, orthorectified, with processing level 3A, provided by MMA for use in projects on the scale of 1: 50,000, PEC-A; (ii) Hydrography dataset granted by The Nature Conservancy - TNC, elaborated in 1:25,000 scale; (iii) Grids of private rural properties and possessions inserted in the Environmental Rural Registry (CAR) of the Integrated Environmental Monitoring and Licensing System of Pará - SIMLAM-PA, managed by State Secretariat for the Environment and Sustainability (SEMAS-PA), obtained on March 13, 2014; Network of properties included in the Rural Environmental Registry (CAR) of the Integrated Environmental Monitoring and Licensing System of Pará - SIMLAM-PA, managed by the State Secretariat for the Environment and Sustainability (SEMAS-PA), obtained on March 13 2014; (iv) Land Use/Cover data elaborated by Project TerraClass (INPE/Embrapa) from 2008 and 2010. In this project, the mapping was performed from Landsat/TM scenes, georeferenced with planimetric quality compatible with the specifications for the scale of 1:100,000 (ALMEIDA et al., 2010).

The activities started with validation and adjustments of the TerraClass 2010 (Figure 2) (DSG, 2016) mapping and CAR grid. For ground truth representation, Rapideye images from 2014 with spatial resolution of 5 meters were used. In the TerraClass de 2010 mapping, source to define the asset and liability environmental areas of the municipality's APP, it was verified that nearly $2 \%$ of the territory was classified as areas "not observed", "deforested" and "others", which may be areas whose source images for mapping presented cloud cover,

FLORESTA, Curitiba, PR, v. 51, n. 2, p. 272-281, abril/jun 2021.

Cicerelli, R. E. et.al.

ISSN eletrônico 1982-4688

DOI: $10.5380 /$ rf.v51 i2. 61804 
deforestations and fires, as indicated in the TerraClass project. In all, 14.664 polygons pertaining to these classes were identified, which underwent editing for reclassification from the visual analysis of the Rapideye scenes. This procedure was carried out to detect ground cover in regions not mapped by TerraClass, however, it is important to highlight that there is a temporal difference between the products that may result in omission errors.

With the adjusted map, a readjustment of the classes was performed, based on the requirements of Law n.12,651, and the generalization redefined 12 information classes for six new classes, called remaining vegetation, capoeira/capoeirinha, hydrography, urban area, agriculture and cattle ranching, and mining.

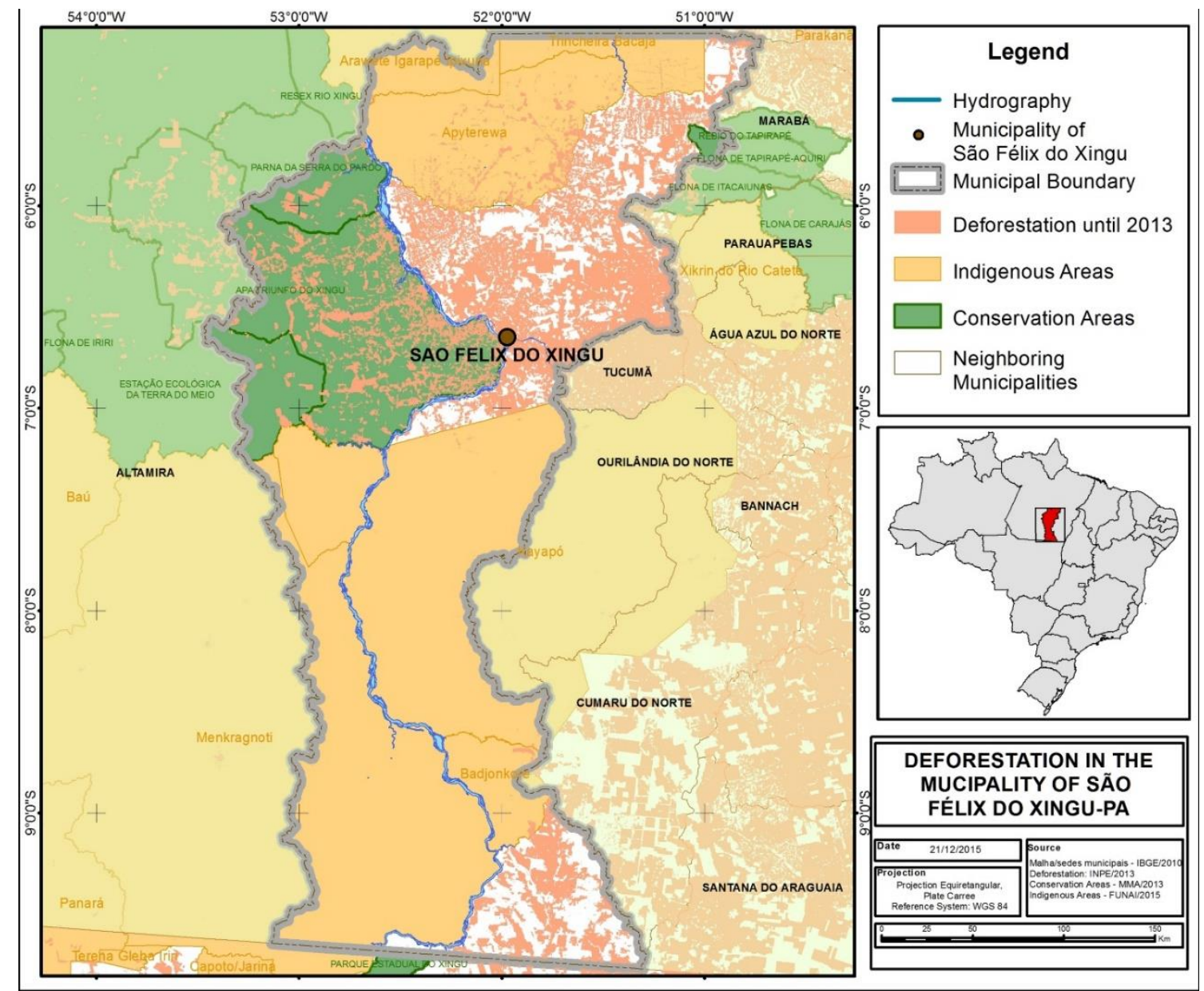

Figura 1. Localização do município de São Félix do Xingu (PA).

Figure 1. Location of the municipality of São Félix do Xingu (PA).

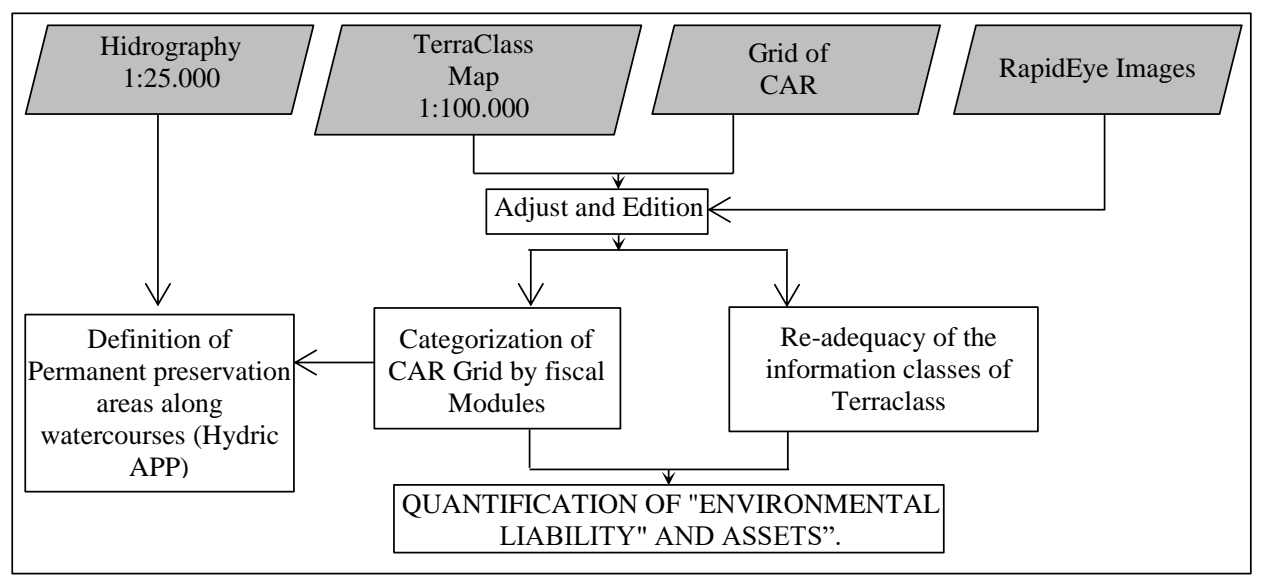

Figura 2. Etapas metodológicas empregadas na pesquisa

Figure 2. Methodological stages used in this research.

FLORESTA, Curitiba, PR, v. 51, n. 2, p. 272-281, abril/jun 2021.

Cicerelli, R. E. et.al.

ISSN eletrônico 1982-4688

DOI: $10.5380 /$ rf.v51 i2. 61804 
The grid of rural properties registered in CAR made available by SEMA-PA was of the Environmental Licensing Monitoring System (SIMLAM). The grid is generated from the union of all individual CAR records entered in the system . As expected, there were several topological errors, such as gaps and overlaps, totaling 16,211 conflicts. Notice that to calculated liabilities it is important that the properties represent the real coverage of the municipality's surface, however, of $32,399,65 \mathrm{~km}^{2}$ of registrable area in the municipality, the CAR grid indicated $42,514.540 \mathrm{~km}^{2}$ of registered area, more than $10 \mathrm{mil} \mathrm{km}$, which represents an overlap of $31 \%$. The problems were assessed individually as of comparison between the images and polygons overlapped. In cases of dubious limits, the most updated CAR limit was the option. Furthermore, the properties overlapping the settlements, indigenous lands, and integral protection conservation units were removed because legally such properties do not exist. However, currently SICAR (Rural Environmental Registration System) accepts the registration in these areas to identify properties that have not yet been expropriated.

It is important to emphasize that the adjustment resulted in an assumption of reality, following some basic requirements to avoid overlaps, and thus cannot be considered official or real data, but is adequate for a general evaluation of the environmental regularization of the municipality. The resulting landholding grid was categorized by size of rural properties, defined to meet the guidelines recommended in the LPVN, which provides for differentiated rules according to the size of the property, by fiscal module categories. (MF - fiscal module - is a rural unit that varies from 5 ha in densely populated areas to 110 ha in sparsely populated areas like the Amazon).

For the quantification of areas irregularly deforested in permanent preservation areas along watercourses, the established rules were observed, according to article $n^{\circ} 4$, item I (Law \# 12,651 / 2012). For the purposes of APP recomposition, the law established some privileges for the continuity of agrosilvopastoral, ecotourism, and rural tourism activities, which vary according to two factors: property size, and river width. For recomposition of the APP along watercourses it is important to observe the existence of consolidated areas on the property, with anthropic occupation previous to July 22, 2008, with buildings, improvements or agrosilvipastoral activities, admitting, in the latter case, the adoption of a fallow regime (art. 3, incise IV, Law 12,651/2012).

The determination of consolidated productive areas on the base date of July 22, 2008 is not trivial because it depends on the interpretation of satellite images acquired at the time. Coincidently, the TerraClass program carried out a mapping in the year 2008, which was used as the starting point for the analyses. Deforestations occurred after referred date, until 2010 in APP area, was considered for the general rule of the APP's for recovery$30 \mathrm{~m}$. The general rule was also applied in rural properties, whose fiscal module was greater than 10, regardless of the base date. Despite the need to obtain the land registry in 2008, the non-existence of CAR records for this year meant that this work used the mirror of the 2014 CAR.

With regard to the environmental obligations of Indigenous Lands, since there is no specific regulation, the irregularly deforested areas in APPs were calculated by the general rule, as were the Conservation Units. Table 1 shows the systemization of the minimum recomposition along watercourses according to property size ranges (art. 61-A ${ }^{\circ}$, Law 12,651/2012).

Tabela 1. Faixas de APP hídrica a recompor

Table 1. Hydric APP ranges to be recomposed

\begin{tabular}{lll}
\hline Strips in Fiscal Modules & Hydrography up to $\mathbf{1 0} \mathbf{~ m}$ & Hydrography $>\mathbf{1 0} \mathbf{~ m}$ \\
\hline Up to 1 & $5 \mathrm{~m}$ & $5 \mathrm{~m}$ \\
From 1 to 2 & $8 \mathrm{~m}$ & $8 \mathrm{~m}$ \\
From 2 to 4 & $15 \mathrm{~m}$ & $15 \mathrm{~m}$ \\
From 4 to $10^{*}$ & $20 \mathrm{~m}$ & $\begin{array}{l}\text { Half the river's width (min. } 30 \mathrm{~m} \text { and max. } 100 \\
\text { m) }\end{array}$ \\
$\begin{array}{l}\text { * This category was changed by Law No. 12,727 (BRASIL, 2012b), in which all properties larger than 4 Fiscal Modules can recompose up to } \\
\text { the limit mentioned. }\end{array}$
\end{tabular}

In calculating the APP to be recovered, in areas without property perimeters, or even in areas with void land, only the buffer around the hydrographic features was considered $(30 \mathrm{~m})$. The Law also equates settlements, from, agrarian reform, with small rural properties, based on the calculation of the ideal fraction, which is the relationship between the total area of the settlement project and the number of settled families. The ideal fraction is used to calculate the area to recompose. As the Sistema de Informações de Projetos de Reforma Agrária (SIPRA) of INCRA (Instituto Nacional de Colonização e Reforma Agrária) there is no clarity regarding the total declared area and number of families (LE TOURNEAU; BURSZTYN, 2010), only the total area of settlement limit was considered for the calculation of ideal fraction.

The procedures set out in the flowchart of Figure 3 were adopted for calculation of liabilities in legal reserve areas. According to Law 12,651/2012, Art. 67, rural properties that on July 22, 2008, held an area of up to 4 (four) MF and that had remnants of native vegetation in percentages lower than those provided in Art. 12, the

FLORESTA, Curitiba, PR, v. 51, n. 2, p. 272-281, abril/jun 2021.

Cicerelli, R. E. et.al.

ISSN eletrônico 1982-4688

DOI: $10.5380 /$ rf.v51 i2. 61804 
Legal Reserve will be comprised by the area occupied with native vegetation present on July 22, 2008, with new conversions for alternative land use prohibited. For rural properties larger than four fiscal modules, the minimum percentages must comply with the quantitative set out in article 12 of Law 12,651/2012, of 80\% for properties located in the forest area. In addition, for recompositing purposes, the region of the municipality of São Félix do Xingu already presents approved Ecologic-Economic Zoning, therefore, 50\% of the real estate is accepted as Legal Reserve for rural real estate regularization purposes (FARIAS et al., 2016).

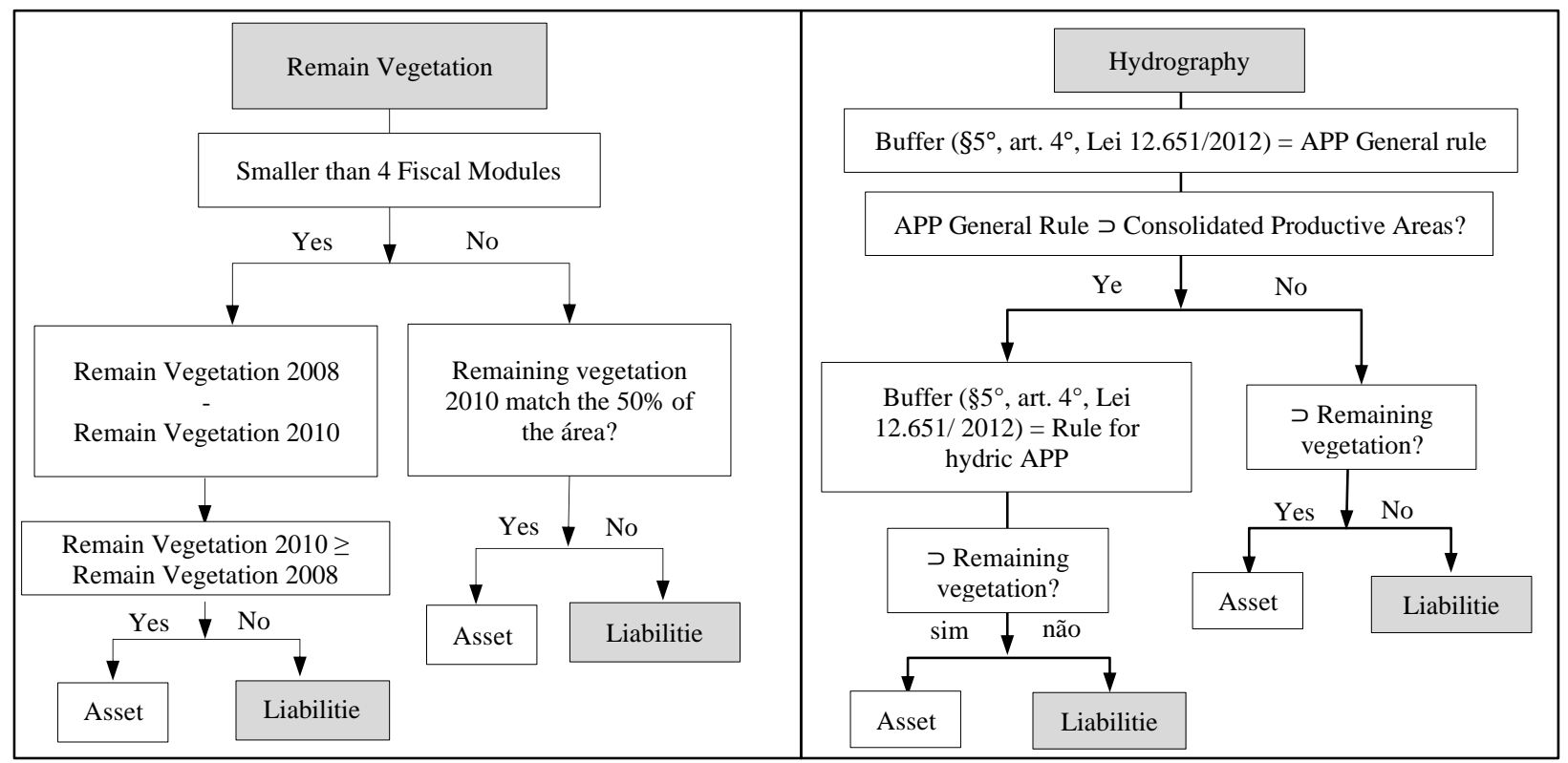

Figura 3. Fluxo de trabalho para o cálculo de passivos em áreas de preservação permanente e em reserva legal. Figure 3. Workflow for calculating liabilities in permanent preservation areas and legal reserves.

In cases of properties smaller than $4 \mathrm{MF}$, obtaining the Legal Reserve became dependent on two factors: size of the property and vegetation cover situation on the base date of July 22, 2008. Firstly, there was no predefined agrarian grid in 2008, thus, the existing CAR grid provided bySEMAS/PA was used in March 2014, which may lead to spurious data in the case of land parceling and remodelling that occurred after 2008. The calculation of the consolidated areas in legal reserves was also performed based on the classes mapped by the TerraClass program in 2008.

Using defined criteria, the data were crossed using the ArcGis 10.2, denominated ModelBuilder to create models from flows that unite a sequence of tools needed to calculate the environmental liabilities.

\section{RESULTS}

Table 2 presents the edited classes from TerraClass mapping for readjusting the classes, based on the categories mentioned in Law 12,651. Using visual interpretation, some of the "non-forest" class was categorized as "Remaining Vegetation" due to the occurrence of natural rocky outcrops. The results of the CAR grid adjustments and classification of the private rural properties and possessions by fiscal modules is presented in Figure 5, which evidences the spatial predominance of properties larger than 10 fiscal modules (750 hectares), mainly in the south region of the municipality and in APA Triunfo do Xingu. According to law \#12,651, such category of rural properties does not receive any benefit regarding reduction of APP and RL. However, there is a tendencyfor rural properties smaller than 4 fiscal modules to be located close to the headquarters of the municipality of São Félix do Xingu.

Tabela 2. Readequação das classes do TerraClass para novas classes de informação em atendimento a LPVN (Lei $\left.\mathrm{n}^{\circ} 12.651\right)$

Table 2. Readjustment of TerraClass classes to new classes of information in compliance with the LPVNC (Law $\left.\mathrm{n}^{\circ} 12.651\right)$ 


\begin{tabular}{ccc}
\hline $\begin{array}{c}\text { Original Classes of the } \\
\text { TerraClass }\end{array}$ & Classes Edited for the Product & Proportion of territory cover \\
\hline Reforestation & Remaining Vegetation & \\
Forest & & \\
Secondary Vegetation \\
Not Forest & & \\
\hline Regeneration with Pasture & Barton/Small Barton & $3,90 \%$ \\
Soiled Pasture & & $1,12 \%$ \\
\hline Hydrography & Hydrography & $0,02 \%$ \\
\hline Urban Area & Urban Area & $13,06 \%$ \\
\hline Mosaic of Occupations & Agriculture & \\
Clean pasture & & $0,02 \%$ \\
\hline Pasture with Exposed Soil & & \\
\hline Mining & Mining & \\
\hline
\end{tabular}

According to Figure 4, although the Environmental Protection Area - APA Trinfo do Xingu is a type of conservation unit, it was considered a registerable area because private rural properties are allowed, with some usage restriction. By adding the area of settlements and of the APA, $86 \%$ of the municipality's registerable territory was included in the CAR up to March 2014. To quantify RL and APP liabilities the above-referred methods were applied in the municipality of São Félix do Xingu and the quantitative per RL and APP category liabilities are presented in Figure 5.

Based on the concept of consolidated productive areas in rural properties smaller than 4 MF and considering the remaining vegetation in 2008 as legal reserve, we verify the existence of $46 \%$ remaining vegetation in rural properties up to $1 \mathrm{MF}, 49 \%$ in properties of 1 to $2 \mathrm{MF}$, and 53\% in properties of 2 to $4 \mathrm{MF}$. We identified 16,469 hectares of environmental liabilities in RL, calculated by the difference between the area of remaining vegetation in 2008 and 2010. Considering that the remaining vegetation of 2010 corresponds to $49 \%$ in rural properties between 4 and $10 \mathrm{MF}$ and $65 \%$ for properties with over $10 \mathrm{MF}$ and, also the reduction of legal reserve to $50 \%$, for recomposition purposes, there was a liability of $1 \%$ (properties between 4 and $10 \mathrm{MF}$ ) and $0 \%$ (properties with over $10 \mathrm{MF}$ ). However, according to the understanding that theLPVN does not authorize deforestation after 2008 and, consequently, the liabilities in these areas would also correspond to the difference in vegetation present in 2008, subtracting the vegetation present in 2010 , there is an RL environmental liability of $45,766.79$ hectares. It is important to note that this rule does not apply to rural properties that have remaining vegetation exceeding $80 \%$ in RL as provided for by LPVN.

Because APA Triunfo do Xingu is considered a sustainable use Conservation Unit that aims to discipline the occupation process and ensure sustainability of natural resources usage, it was analyzed in separate. However, one must consider that the resulting liability quantitative has already been accounted for in areas with CAR, categorized by fiscal modules. The results showed that despite the APA having remaining vegetation of $75 \%$, after 2008 , a reduction of 32,873 hectares of the remaining vegetation until 2010 was already diagnosed, which can be considered RL liabilities following the logic presented above.

Considering the results presented for RL, it can be seen that the category of rural properties larger than 10 fiscal modules, the APA Triunfo do Xingu, and Settlement Projects (PA) are categories that present, in 2008, a low environmental liability value compared with the other categories. However, since the process of clear cutting has continued, the environmental liabilities are now considered significant, with quantities between 30,000 and 54,000 hectares. . For areas not registered in the CAR and the UC and IT areas, the methodology does not apply adequately, since in the first case there is no delimitation of the properties and in the others (UC and IT) the legislation does not provide for this modality. The RL liability of the categories presented was 88,659 hectares. Furthermore, to confirm whether the environmental liability is due to illegal deforestation, it would be important to consult the environmental licenses issued by the Secretary of Environment of the State of Pará. 


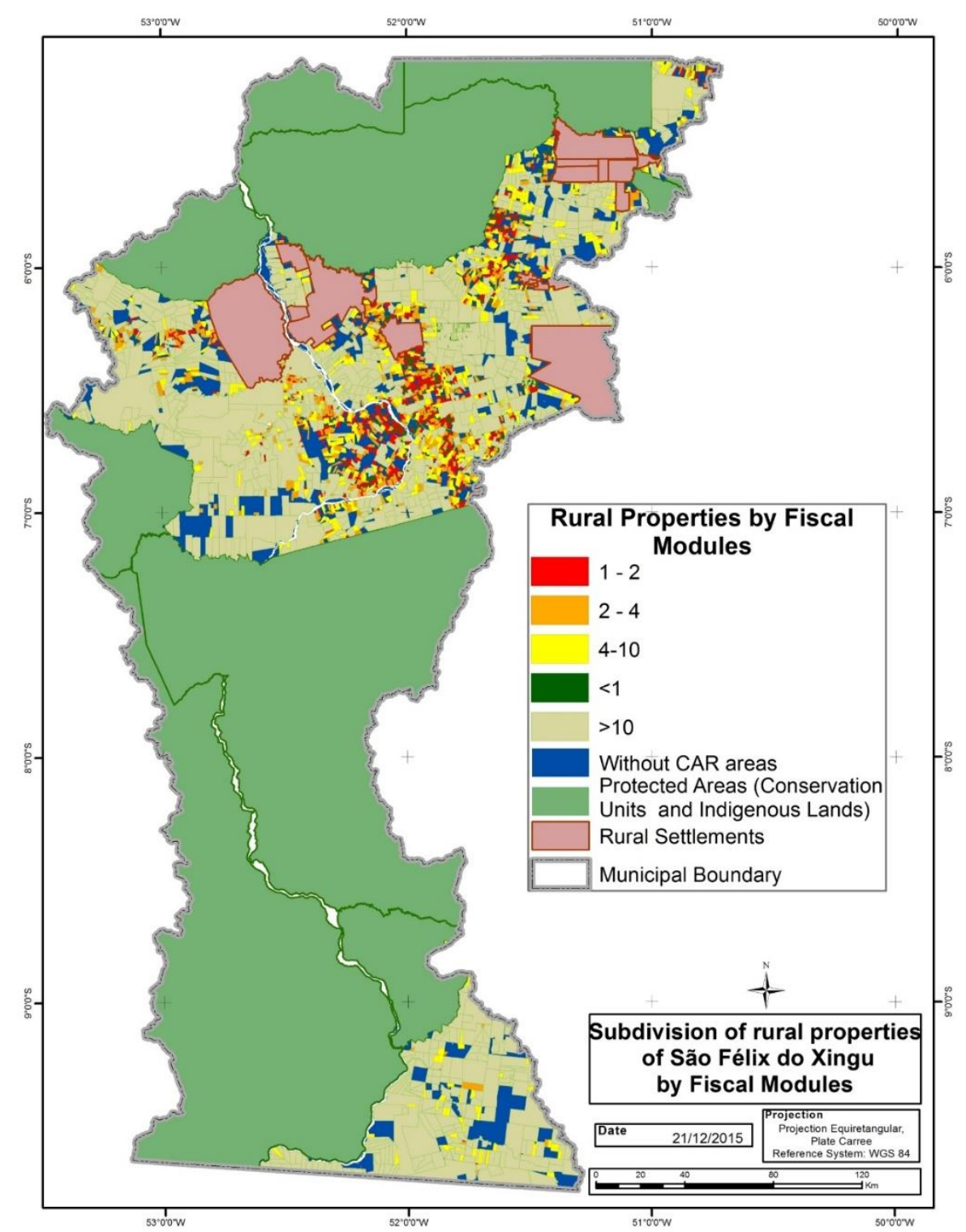

Figura 4. Subdivisão dos imóveis de São Félix do Xingu por módulos fiscais. Figure 4. Subdivision of São Félix do Xingu property by size.

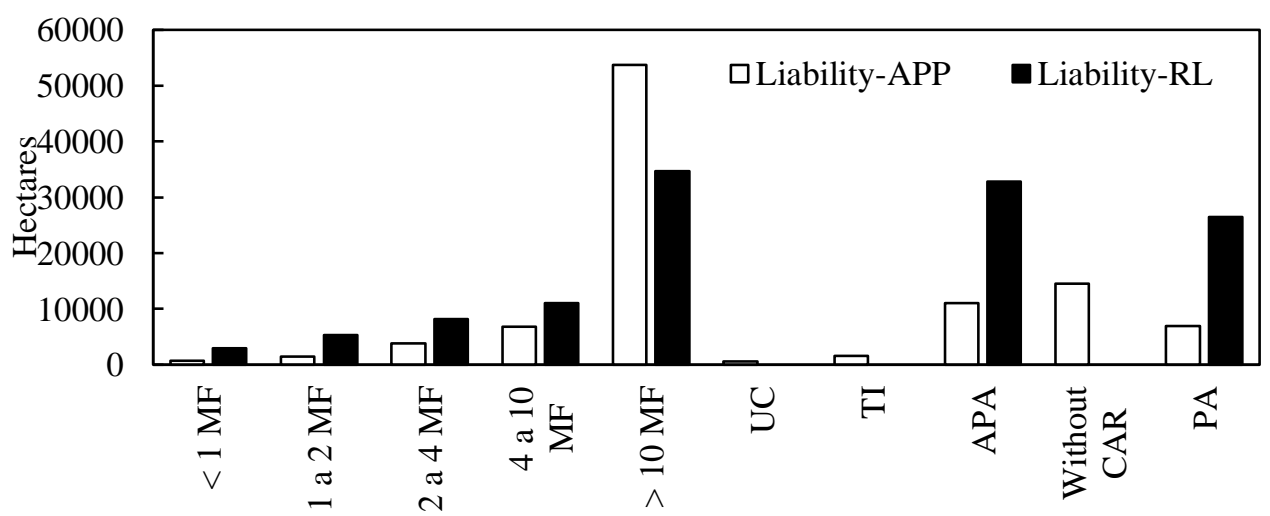

Figura 5. Quantificação de passivos de APP e RL. PA=Projeto de assentamentos; UC =Unidades de conservação; TI=Terras Indígenas; APA=Área de Proteção Ambiental Triunfo do Xingu; MF = Módulos Fiscais

Figure 5. Quantification of APP and RL liabilities. PA = Settlement project; UC $=$ Conservation units; TI = Indigenous Lands; APA = Triunfo do Xingu Environmental Protection Area; MF = property by size.

FLORESTA, Curitiba, PR, v. 51, n. 2, p. 272-281, abril/jun 2021.

Cicerelli, R. E. et.al.

ISSN eletrônico 1982-4688

DOI: $10.5380 /$ rf.v51 i2. 61804 
According to Figure 5, the total liability quantitative of hydric APP in rural property defined in the CAR grid was of 90,176 hectares. For areas without CAR, the total value was of 14,569 hectares, however, notice that in these regions there was no calculation of the benefit called for in Law 12,651 for rural properties by fiscal modules. Considering hydric APP and legal reserve, the environmental liabilities of areas with CAR totaled 178.835 hectares. The Indigenous Land with the largest liability is the Apyterewa (Figure 1), located on the north portion of the municipality. Strong pressure to the south is notices in this area due to land occupation. Prior to the consolidation of such Indigenous Lands a proportion of that land was occupied by squatters, which in some cases are still in the region.

The largest areas with APP liabilities are located on the properties with more than 10 fiscal modules (Figure 5). Mapping of the areas with liabilities in hydric APP in São Félix do Xingu-PA showed that these concentrates mostly in private areas (Figure 6) and there is a tendency for PPA liabilities to occur together with areas that suffered clear-cutting of natural vegetation. This scenario also reveals the rural producers' lack of perception of the environmental services provided by the APP. Figure 6 also reveals that despite the occurrence of deforestation areas, the Indigenous Lands and integral protection Conservation Units carry out control over deforestation advance, with the exception of the more northern Indigenous Lands, where it is possible to observe small spots of deforestation on permanent preservation areas (APP).

\section{DISCUSSION}

Brazil faces an enormous challenge to implement its LPVN, as the law introduces new mechanisms to facilitate the control and monitoring private and public lands such as the CAR, the Environmental Regularization Program (PRA) or the program to support and encourage environmental conservation (SPAROVEK et al., 2015). Considering the amnesties and exemptions established by legislation, most private rural properties, specially the small rural properties analysed, met the requirements until the year 2010. This finding was also observed in Faria et al. (2019) in the Southwest region of Paraná.

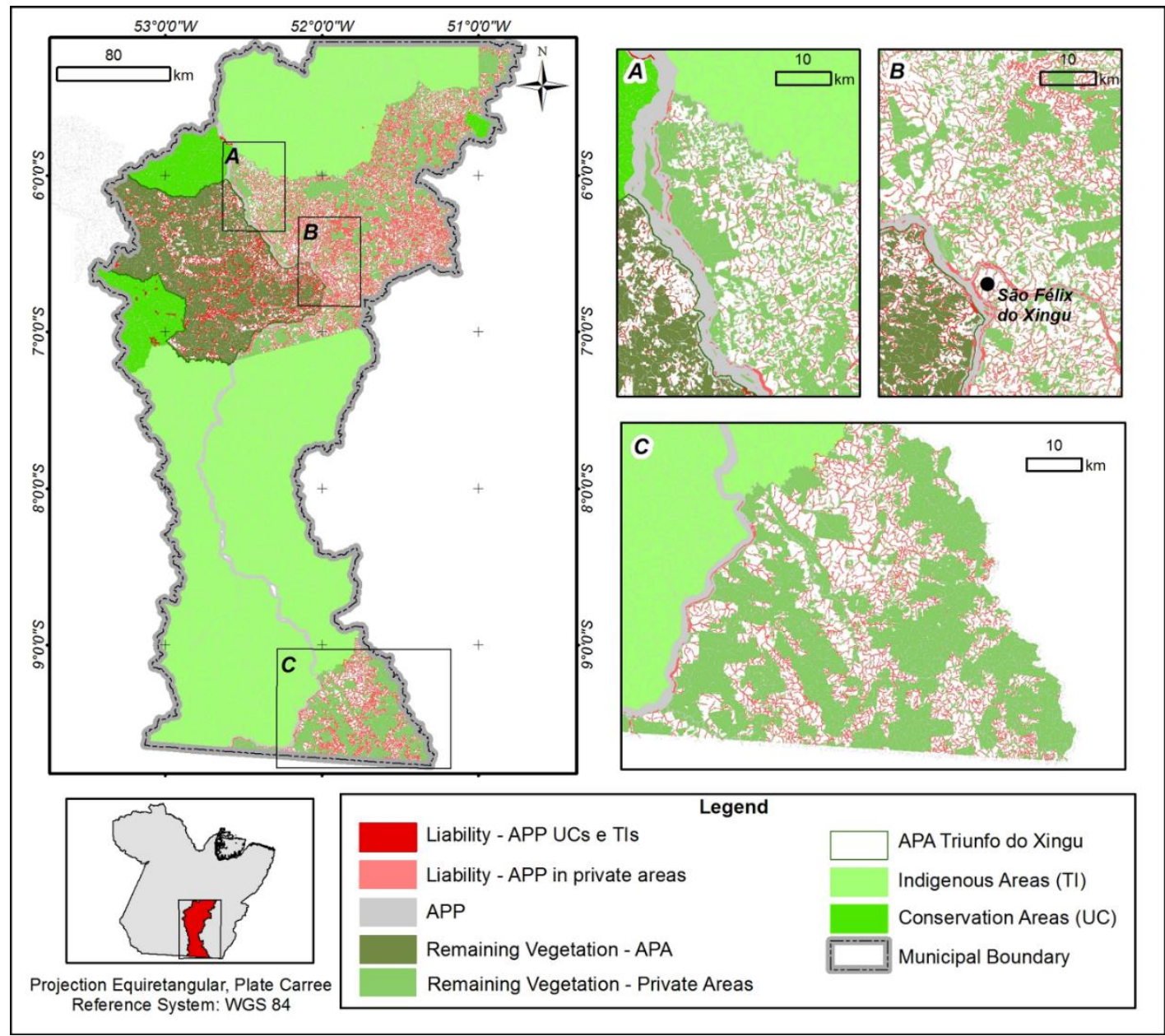

Figura 6. Mapa dos passivos ambientais em áreas de preservação permanente em rios e nascentes em São Félix do Xingu.

FLORESTA, Curitiba, PR, v. 51, n. 2, p. 272-281, abril/jun 2021.

Cicerelli, R. E. et.al.

ISSN eletrônico 1982-4688

DOI: $10.5380 /$ rf.v51 i2. 61804 
Figure 6. Map of environmental liabilities in permanent preservation areas in rivers and springs in São Félix do Xingu.

The main beneficiaries were the settlements, for being in environmental compliance with the changes as a result of the adaptation of article 61-C, and the situation of rural properties in consolidated productive areas, according to requirements established in article 61-A. Feistauer et al. (2014) e Le Tourneau (2010) also made the same observations on the environmental adequacy of settlements. Despite this, it is important to carry out technical analyses about hydric resources at these locations, since they are areas of family production, and require investments from the public segment for the maintenance of natural resources and sustainable production..

For future work, it is recommended that the calculation of the environmental liability be updated using the 2012 TerraClass mapping or MAPBIOMAS. The applied methodology can also be improved with the implementation of tools that automate the process. In addition, new inputs can be generated, such as, for example, the identification of properties with forest assets to strengthen the support of program for environmental conservation, provided for in art. 41. This benefit aims to pay or encourage environmental services in return for conservation activities and improvement of ecosystems that generate environmental services.

São Felix do Xingu is still a municipality with a large area of environmental assets which allows the use of benefits provided for in the LPVN, such as, for example, payment for ecosystem services (PSE - Pagamento por Serviços Ecossistêmicos). The most promising of these is forest certification, or, as it is sometimes called green certification, that aims to identify forestland that is managed to meet agreed-upon standards to market for the sale (CRAs - Cotas de Reserva Legal/Environmental Reserve Quotas). This program allows landowners to offset their restoration obligations by paying for the maintenance of native vegetation elsewhere (SOARES-FILHO et al., 2014; SOARES-FILHO et al., 2016; ARAGÃO et al., 2014). This discussion about surplus RL forests is still incipient, but promising, since these areas may be marketed in CRAs, among producers who wish to recover their RL in locations other than those of the rural property (FARIAS et al., 2019; DA CRUZ et al., 2020). Another possibility to regularize rural properties, would be with the recovery of degraded pastures or the conservation of secondary vegetation. Besides complying with the law, this strategy could also promote the recovery of local biodiversity and, indirectly, create a more consistent form of destination for areas with low agricultural potential (MARTINI et al., 2015).

\section{CONCLUSIONS}

- The survey of pre-existing information and the systematic analysis of the data allowed the identification of private rural properties and possessions with the quantification of forest assets and liabilities, which strengthen the support and monitoring programs and the incentive to environmental preservation and environmental recovery, foreseen in art. 41 of Law no. 12,651.

- Despite the efforts to edit and improve the data, it is evident that the results obtained in this study indicate the limitation related to basic municipal cartography and the mesh of rural property limits provided by the CAR. The difficulty in building robust and reliable agrarian networks is limiting factors in the calculation and identification of environmental liabilities environmental assets, which result in the slowness of environmental recovery. The use of classes related to the category of fiscal modules, reduced the problems caused by the lack of quality of inputs and guaranteed a vision with municipal spatial distribution of illegal deforestation. Thus, such a proposal can be successfully applied to municipal scale.

- In São Félix do Xingu, the largest environmental liability identified was for properties greater than 10 fiscal modules. The exponential development of the environmental liability of this category, in the temporal analysis between 2008 and 2010, indicates a tendencyfor the following years. In other words, the monitoring must be constant to preserve the remaining forest.

- APA Triunfo do Xingu is a region that needs immediate action to contain disorderly occupation, since the production area allows only regulated use of the soil.

\section{ACKNOWLEDGMENTS}

The authors thank the Ministry of the Environment (MMA) and the United Nations Food and Agriculture Organization (FAO) for the availability of data. To ESRI for making the ArcGIS 10.x tool package available through the contract \#2011 MLK 8733. To the IMAGEM company for the support and fulfillment of the term of usage between the Geosciences Institute and ESRI and software support services.

\section{REFERENCES}

ALMEIDA, C. A.; VALERIANO, D. M.; ESCADA, I. S.; RENNÓ, C. D. Estimativa de área de vegetação secundária na Amazônia Legal Brasileira. Acta Amazonica, v. 40, n. 2, p. 289-301, 2010. 
ARAGÃO, L.E.O.C.; POULTER, B.; BARLOW, J. B.; ANDERSON, L. O.; MALHI, Y.; SAATCHI, S.; PHILLIPS, O. L.; GLOOR, E. Environmental change and the carbon balance of Amazonian forests. Biological Reviews, v. 89, n. 4, p. 913-931, 2014.

BARNI, P. E.; FEARNSIDE, P. M.; GRAÇA, P. M. L. A. Desmatamento no sul do Estado de Roraima: padrões de distribuição em função de Projetos de Assentamento do INCRA e da distância das principais rodovias (BR-174 e BR210). Acta Amazonica, v. 42, n. 2, p. 195-204, 2012.

BECKER, B. K. Revisão das políticas de ocupação da Amazônia: é possível identificar modelos para projetar cenários? Parcerias estratégicas, v. 6, n. 12, p. 135-159, 2010.

BRASIL. Lei n ${ }^{\circ} 12.651$, de 25 de maio de 2012. Dispõe sobre a proteção da vegetação nativa; altera as Leis nos 6.938, de 31 de agosto de 1981, 9.393, de 19 de dezembro de 1996, e 11.428, de 22 de dezembro de 2006; revoga as Leis nos 4.771, de 15 de setembro de 1965, e 7.754, de 14 de abril de 1989, ea Medida Provisória no 2.166-67, de 24 de agosto de 2001; e dá outras providências. Diário Oficial da União, 2012.

BRASIL. Lei $\mathrm{n}^{\circ}$ 12.727, de 17 de outubro de 2012b. Altera a Lei no 12.651, de 25 de maio de 2012, que dispõe sobre a proteção da vegetação nativa; altera as Leis nos 6.938, de 31 de agosto de 1981, 9.393, de 19 de dezembro de 1996, e 11.428, de 22 de dezembro de 2006; e revoga as Leis nos 4.771, de 15 de setembro de 1965, e 7.754, de 14 de abril de 1989, a Medida Provisória no 2.166-67, de 24 de agosto de 2001, o item 22 do inciso II do art. 167 da Lei no 6.015, de 31 de dezembro de 1973, eo $\S 2^{\circ}$ do art. $4^{\circ}$. Diário Oficial [da] República Federativa do Brasil, 2012.

BOUCHER, D.; ROQUEMORE, S.; FITZHUGH, E. Brazil's success in reducing deforestation. Tropical Conservation Science, v. 6, n. 3, p. 426-445, 2013.

COUTINHO, A. C. Condicionantes da expansão da fronteira agrícola em Mato Grosso. Revista de Política Agrícola, v.1, p. 80-97, 2009.

DA CRUZ, Júlio César; BARELLA, César Falcão; FONSECA, Alberto. Compensating deforestation with forest surplus: Key regulatory issues within Brazil's atlantic forest. Ecological Economics, v. 167, p. 106444, 2020.

DALLA-NORA, E. L.; AGUIAR, A. P. D.; LAPOLA, D. M.; WOLTJER, G. Why have land use change models for the Amazon failed to capture the amount of deforestation over the last decade? Land use policy, v. 39, p. 403-411, 2014.

DSG (Diretoria do Serviço Geográfico). Especificação Técnica Para Controle de Qualidade de Dados Geoespaciais (ETCQDG). Brasília, Brasil, 2016.

FARIAS, M. H. C. S.; BELTRÃO, N. E. S.; SANTOS, C. A.; CORDEIRO, Y. E. M. Zoneamento Ecológico-Econômico do Estado do Pará: fundamentos e potencialidade. Revista Geográfica Acadêmica, v. 10, n. 1, p. 17-26, 2016.

FARIA, A. B. C.; PERTILlE, C. T.; MIRANDA, F. D. A. Análise da adequação florestal de pequenas propriedades rurais no sudoeste do Paraná. Ciência Florestal, v. 29, n. 1, p. 432-443, 2019.

FEISTAUER, D.; LOVATO, P. E.; SIMINSKI, A.; RESENDE, S. A. Impactos do novo código florestal na regularização ambiental de propriedades rurais familiares. Ciência Florestal, v. 24, n. 3, p. 749-757, 2014.

GUEDES, F. B.; SEEHUSEN, S. E. Pagamentos por serviços ambientais na Mata Atlântica: lições aprendidas e desafios. Brasília: MMA, v. 272, 2011.

LE TOURNEAU, F. M.; BURSZTYN, M. Assentamentos rurais na Amazônia: contradições entre a política agrária e a política ambiental. Ambiente \& Sociedade, v. 13, n. 1, p. 111-130, 2010.

MACEDO, M. R. A.; DARNET, L. A. F.; THALÊS, M. C; POCCARD-CHAPUIS, R. Configuração espacial do desflorestamento em fronteira agrícola na Amazônia: um estudo de caso na região de São Félix do Xingu, Estado do Pará. Revista Nera, n. 22, p. 96-110, 2013.

MACEDO, M. N.; DEFRIES, R. S.; MORTON, D.; STICKLER, C. M.; GALFORD, G. L.; SHIMABUKURO, Y. E. Decoupling of deforestation and soy production in the southern Amazon during the late 2000s. Proceedings of the National Academy of Sciences, v. 109, n. 4, p. 1341-1346, 2012.

MARTINI, D. Z.; MOREIRA, M. A.; ARAGÃO, L. E. O. C.; FORMAGGIO, A. R.; DALLA-NORA, E. L. Potential land availability for agricultural expansion in the Brazilian Amazon. Land Use Policy, v. 49, p. 35-42, 2015.

MCNEELY, J. A.; HARRISON, J. Protecting nature: regional reviews of protected areas. IUCN, 1994.

SOARES-FILHO, B.; RAJÃO, R.; MACEDO, M.; CARNEIRO, A.; COSTA, W.; COE, M.; RODRIGUES, H.; ALENCAR, A. Cracking Brazil's forest code. Science, v. 344, n. 6182, p. 363-364, 2014.

SOARES-FILHO, B.; RAJÃO, R.; MERRY, F.; RODRIGUES, H.; DAVIS, J.; LIMA, L.; MACEDO, M.; COE, M.; CARNEIRO, A.; SANTIAGO, L. Brazil's market for trading forest certificates. PLoS One, v. 11, n. 4, 2016.

SPAROVEK, G.; BARRETTO, A. G. O. P.; MATSUMOTO, M.; BERNDES, G. Effects of governance on availability of land for agriculture and conservation in Brazil. Environmental science \& technology, v. 49, n. 17, p. 10285-10293, 2015.

FLORESTA, Curitiba, PR, v. 51, n. 2, p. 272-281, abril/jun 2021.

Cicerelli, R. E. et.al.

ISSN eletrônico 1982-4688

DOI: $10.5380 /$ rf.v51 i2. 61804 